\title{
LEGAL COMPLEXITY AND THE TRANSFORMATION OF THE CRIMINAL PROCESS: THE ORIGINS OF PLEA BARGAINING*
}

\author{
Malcolm M. Feeley**
}

\section{Introduction}

The standard form of disposition for most English and American criminal cases is the guilty plea, by means of a plea bargain. Jury trials are the rare exception rather than the rule. Although plea bargaining is the subject of a huge scholarly literature analyzing its nature and functioning, there is a much smaller literature on its origins and development. Most of the literature is highly critical, and much of it rests upon a belief that bureaucratic justice has come to replace the vigorous adversarial jury trial. Some critics lament "our vanishing jury". ${ }^{1}$ Others decry the rise of "technocratic justice". ${ }^{2}$ And still others warn that we are witnessing the "twilight of the adversary process", ${ }^{3}$ or the decline of the adversary system. ${ }^{4}$ Even those who defend plea bargaining, such as justices on the United States Supreme Court, tend to regard it as a "necessary evil" required as an expedient to cope with the rising tide of caseloads rather than an ideal process.

Despite important differences of emphasis among these and still other commentators, most share an important commonalty; they adopt a form of functional analysis that understands plea bargaining as an adaptation to caseload pressures. Hence the power of the metaphor "the twilight" of the adversary process. This assessment seems plausible in light of pervasive plea bargaining and the crush of caseloads in American and English courts. And when we compare the relative infrequency of jury trials in late twentieth century America and Great Britain with

* This is a revision of a paper presented at the Conference, Rights of the Accused, Crime Control, and the Protection of Victims, Jerusalem, December 19-22, 1993.

** School of Law, University of California at Berkeley.

1 Raymond Moley, "The Vanishing Jury Trial", (1928) 2 So. Calif. L.R. 97.

2 Wolf Heydebrand and Carroll Seron, Technocratic Justice (1987).

3 Abraham Blumberg, Criminal Justice (1967).

4 See, e.g., Albert Alschuler, "The Prosecutor's Role in Plea Bargaining", (1968) 36 U. of Chicago L.R. 50; Albert Alschuler, "Plea Bargaining and its History", (1969) 13 Law and Soc. R. 211; and Stephen Landsman, "The Rise of the Contentious Spirit: Adversary Procedure in Eighteenth Century England", (1990) 75 Cornell L.R. 497. 
their frequency in the early nineteenth century, claims of the demise or twilight appears still more convincing.

However, in this article I want to problematize these and similar claims about the decline of the jury trial and the rise of the guilty plea process and plea bargaining. I want to subject them to careful scrutiny, and examine them in historical context. Most discussions of plea bargaining shift from a functional to an historical analysis without an adequate basis. They imply a history (of ever-increasing caseloads that create pressure to replace the adversarial trial with a more efficient form of disposition) rather than document one. As a consequence, assertions about the "decline" or "twilight" or "demise" of the adversary process do not rest on solid foundation. Indeed, I will show that the critics who make such claims tend to compare contemporary plea bargaining against a set of non-existent practices of yesteryear. Or, they contrast plea bargaining against a set of standards garnered from today's and not yesterday's trials. More centrally, however, I want to place the rise of the guilty plea process and plea bargaining and the decline of the jury trial in criminal cases in historical context, to examine the nature of the criminal trial when it was widely used and to identify and explore the factors that led to its decline.

The "functional fallacy", - that is implying a casual historical process from a functional analysis of contemporary processes - is easy enough to make. Observers see busy courts, contrast rapid-paced plea bargaining with time-consuming trials, and knowing that trials once were the norm rather than the exception, conclude that plea bargaining is an adaptation to the pressure of heavy caseloads. But such a conclusion invents or assumes a history rather than describes and explores it. However persuasive it may seem, such functional analysis does not explain why the practice of plea bargaining grew up in the first place, or why today it is so pervasive, even in courts without heavy caseload pressures. Indeed, without more evidence, there is no clear and convincing evidence that caseload pressures have increased over time. Above all, a functional analysis has a fixed notion of the jury trial based upon the contemporary trial; it does not link the emergence of plea bargaining with the evolution of the jury trial.

Thus the second problem, the issue of the "twilight" of the jury trial. Observers contrast careful contested jury trials to rapid-fire and perfunctory plea bargaining, and find the latter wanting by comparison and lament that the latter has replaced the former. Such comparison is reasonable, but by itself is not evidence of the decline of the adversary 
system. Again, an historical analysis is called for. To explore the issue of "twilight", one must ask what the "high noon" and "dawn" looked like. What did trials look like prior to the rise of plea bargaining?

This article explores these two inter-related issues. It traces the decline of the trial and the rise of plea bargaining, as well as explores changes in the nature of the jury trial system. It analyzes patterns in over 3500 cases drawn from a sample of London's Central Criminal Court, long known as The Old Bailey, from 1687, shortly after records first began to be systematically kept, to $1912 . .^{5}$ This investigation,

According to various authorities this court was established by a charter from Henry I early in the twelfth century. Beginning in the late middle ages its jurisdiction was roughly equivalent to that of the combined jurisdictions of the crown courts of Quarter Sessions and Assizes, those courts which handled indictable offenses for the rest of England and Wales. When it was established the crown granted the court at The Old Bailey special criminal jurisdiction for the City of London which was later expanded to include Westminster and parts of Middlesex. This special jurisdiction has remained intact for centuries, although functionally The Old Bailey is the equivalent of the courts of assizes in other areas of the country. This distinctiveness is in part accounted for by the idiosyncrasies of English tradition and by the fact that The Old Bailey was the criminal court for one of the most densely populated and crime ridden areas in the country. This in turn is complicated by the fact that the City of London is located at the confluence of several counties (the City of London, Middlesex, Essex, Kent and Surrey). Thus the court is in effect a special district designed to meet a particular problem and circumvent problems of multiple jurisdiction. As a special area-wide court it facilitated handling large numbers of criminal matters, and was in session more-or-less continuously (rather than quarterly or occasionally as were the courts of Quarter Sessions and Assizes). In 1834 the City of London, all of Middlesex County and parts of Essex, Kent and Surrey were designated as a single venue for the purposes of indictments and crime, and The Old Bailey was given a new name, the Central Criminal Court. Still long after 1834 this court continued to be called The Old Bailey, and so we shall use this term in this paper.

The Old Bailey is distinctive for still another reason. Located in inner London it heard more than its share of the country's criminal cases. And as it was near the Inns of Court and Fleet Street, it has had more than its share of attention from lawyers and the press. Those familiar with the modern history of English criminal justice - the developments of a stipendiary magistracy and a professional police force, and the agitation for reform of the criminal law - know that most of these movements were first spawned in metropolitan London. And in the metropolis, the court at Old Bailey was often the object of the critics' wrath and the reformers' good intentions.

These distinctive features make it a good object of focus for our purposes. Its proceedings were documented in its Sessions papers, and because it was the nation's busiest and most well-known criminal court, it anticipated national trends. 
largely a quantitative analysis of the sample of these cases, part of an on-going investigation in long-term changes in the criminal process, traces the bare-bones features of major changes in the nature and functioning of the criminal trial during a period of over two hundred years. In this article, I focus on changes and the functioning of the jury trial, and more particularly the origins of its decline and replacement by the guilty plea and plea bargaining process. ${ }^{6}$

The results of this inquiry stand in sharp contrast to conventional discussions of plea bargaining. I show that adversariness and plea bargaining are directly related, that adversariness has expanded in direct proportion to the growth of plea bargaining. Further, I show that both plea bargaining and the vigorously contested jury trial emerged as a result of the same sets of factors-expanding rather than contracting resources for and increased adversarial opportunities in the criminal process. Rather than being opposed to each other, both the vigorous trial and the modern guilty plea process are products of the same developments.

This analysis should not be taken as a "defense" of plea bargaining. However, it does attempt to locate plea bargaining in historical perspective, and by doing so seeks to expose some of the myths about the origins and functioning of plea bargaining and about jury trials. By identifying the importance of hitherto un- or under-recognized factors shaping criminal adjudication, I hope to correct misunderstandings that have misinformed much contemporary analysis of the subject. Below, in Part I, I outline a framework for exploring the rise of plea bargaining and the decline of the jury trial. Part II provides an historical analysis of the nature of the jury trial and identifies factors that account for both its expansion and its decline. Part III, examines the causes and consequences of a "bifurcated" criminal process (jury trials and plea bargaining). Part IV discusses the impact of lawyers - rather than caseloads - as the important factor leading to changes in the criminal process.

6 For other reports on this continuing project and the importance of the expansion of defense counsel, see Malcolm M. Feeley, "Plea Bargaining and the Structure of the Criminal Process", (1978) 4 Justice System Journal 394; Malcolm M. Feeley, The Process is the Punishment: Handing Cases in a Lower Criminal Court (1979) 135-152, and Malcolm M. Feeley and Charles Lester, "Legal Complexity and the Transformation of the Criminal Process", in Andre Gouron, Laurent Mayali, Antonio Padoa Schioppa und Dieter Simion, eds., Subjektivierung des justiziellen Beweisverfahrens (1994) 337. 
One warning. What follows is a work-in-progress, only the skeleton of an argument that has yet to be fleshed out. Still, presentation of this skeleton is valuable. It reveals in stark form the bare bones and connecting structures. Since my thesis runs counter to so much of the literature, it may be particularly useful to set out the essentials of my position in stark form.

\section{A Framework for Understanding Pleas}

This article argues that plea bargaining emerged as a consequence of increased resources and enhanced opportunities for adversarial justice-increased presence of lawyers, refinements in the rules of criminal procedure and evidence, and changes in the substantive criminal law. In the larger on-going project, I explore four sets of factors: 1) the theory and assumptions of an adversary process rooted in a tradition of private prosecution; 2) changes in the substantive criminal law; 3 ) changes in the rules of criminal procedure and evidence; and 4) the rise of full-time, law-trained "professionals" who supplemented or replaced lay decisionmakers. An examination of all of these factors is beyond the scope of this article, and I concentrate on the last two, changing features procedure and evidence, and the growing importance of "professionals". An examination of these factors, I will show, reveals that the guilty plea process and plea bargaining is not an adaptive measure which emerged to cope with limitations of resources, but is a direct consequence of increases in resources and opportunities for adversariness.

\section{The Trial before Plea Bargaining}

Was there a time when trials were the dominant mode of adjudication? In a word, yes. A review of Anglo-American court records reveals that disposition by means of guilty pleas in serious criminal cases began in the mid-nineteenth century. Sometime in the mid-nineteenth century guilty pleas in the more serious cases grew dramatically and trial rates declined. In London's Old Bailey in the 1830 s, trials accounted for over ninety-five percent of all adjudication. In Superior Court in New York City in 1846, 75 percent of all dispositions were by trials, but by 1860 this figure had declined to 53 percent. By 1919, it was 88 percent. Similarly in New Haven, Connecticut, during roughly the same period 
trials declined from 79 percent in 1837 to 50 percent in 1888 , and to three percent in $1934 .{ }^{7}$ By the 1920s, trials accounted for less than 15 percent of all adjudications in Cleveland and Chicago. ${ }^{8}$ Figures for still other American jurisdictions reveal a similar pattern..$^{9}$ Furthermore in the mid to late nineteenth century, the practice of plea switching - from not guilty to guilty on a reduced charge - also became common place, an indicator that plea bargaining had taken root.

At first glance, such figures appear to support the "twilight thesis": guilty pleas and pleas to reduced charges came to replace the combative jury trial. But let us penetrate the surface of such figures and consider the substance of the process in some detail. Once we do, the "twilight" thesis loses its luster. Indeed, it can be stood on its head. the emergence of plea bargaining is a response to an increased capacity for adversariness. But to sustain such a claim, we must go beyond jury trial rates and examine the nature of jury trial more closely. Two issues concern us here: What were trials like in this earlier era when they were more frequent? And, what is entailed in the modern guilty plea process?

Contemporary accounts of the trial process in eighteenth and nineteenth century London and elsewhere reveal practices that are at odds with the contemporary image of the jury trial: Typically defendants were not represented by lawyers (indeed in England until 1836, as a matter of law in felony cases lawyers could not address the jury); they rarely confronted witnesses in any meaningful way; they rarely challenged evidence or offered defenses of any kind. And when the accused or someone in his or her behalf did occasionally take the stand, more often than not, they did not offer a spirited defense, but offered perfunctory excuses or defenses, plead for mercy, or in the case of witnesses, offered testimony as to good character or mitigating factors.

Indeed the eighteenth century and early nineteenth century trial (and earlier) more closely resembled the modern sentence hearing or plea bargaining process than it does a full-fledged modern jury trial. The proceedings merged concern with guilt with consideration of punishment, just as critics of contemporary plea bargaining maintain that plea bargaining does. Typically the accused's role in the trial was to offer mitigating factors or offered testimony of good character in the

8 Moley, supra n. 1.

9 See, e.g., Alschuler, supra n. 4. 
hope that the full harshness of the law could be avoided, just as discussions in modern plea negotiations often do. Indeed, defenses before the jury regularly consisted of pleas for mercy, testimony of good character, and emphasis of mitigating factors. Frequently these hopes were fulfilled by means of an acquittal or conviction on reduced charges by the jury, or after a conviction a successful recommendation for mercy by the jury and/or judge.

As illustration, consider the following defenses in two jury trials at the Old Bailey in 1815: The first, Thomas Walker, age 47, was "indicted for feloniously stealing, on the 14th of April, a pair of silver tea-tongs, value $4 \mathrm{~s}$., two silver cannister tops, value $24 \mathrm{~s}$, a wine strainer, value $7 \mathrm{~s}$., a mantle of cloak, value 30s. and an umbrella, value 2s. the goods of John Cairns, in his dwelling-house." Walker had been a lodger in the home of the prosecutrix [Mrs. Cairns] until the day of the theft of these items, which were soon discovered in a pawnbroker's shop and traced to Walker. After brief testimony at trial by the prosecutrix identifying the goods as hers and by a fellow lodger at Walker's new lodgings which linked the items to Walker, Walker testified: "I am sunk down with shame. I am not one of those persons that live by plundering the public; I hope you can extend as much mercy towards me as you can". Liable to be transported if convicted of theft for the stated value of the goods, the jury found him guilty of stealing, but declared the value of the items stolen to be 30s., just below the threshold for transportation. In addition the jury "recommend[ed] him to mercy in the strongest terms". The Court obliged, sentencing him "to be confined for one month and fined $1 s^{\prime \prime}$.

On that same day the same judge and jury also tried Samuel Munday for feloniously stealing on the 11th of April, twenty-six yards of gingham, value 2l., the goods of George Todd, in his dwelling-house". After testimony from the constable who arrested him in possession of the goods, Munday appeared in his own defense before the jury, and said: "I never until now have been called to answer a dishonest charge". The jury convicted him of stealing "to the value of 39s., and the judge imposed a sentence of six months imprisonment and a fine of $1 \mathrm{s.}{ }^{10}$

Although there were occasional long and drawn out trials, with numerous witnesses, conflicting testimony, and the like, typically the accused, like Walker and Munday described above, were unrepresented 
by counsel as were the victims who prosecuted them, and their defenses consisted of mixtures of weak denial, pleas for mercy, and testimony of good character in a brief trial. What is perhaps even more revealing about these and the vast majority of other jury trials in the eighteenth and early nineteenth century was their brevity. Records of proceedings indicate that the same judge and jury might hear several cases per day with hardly a pause between them. The trials of Walker and Munday mentioned above were two of several heard by the same judge and jury at the same sitting, and both lasted only a few minutes. Thomas Wontner, a chaplain at the Old Bailey in the early nineteenth century who wrote a book criticizing hurly-burly practices in the court, timed the length of jury trials and reported that they lasted on average eight minutes. ${ }^{11}$ In New Haven, Connecticut at roughly the same period, the court register reveals that it was common for the same judge and jury to hear several felony cases at one sitting and then adjourn to deliberate on them all. ${ }^{12}$ Even when this did not occur, trial and sentencing could both occur within the span of an hour or two.

This brief examination points to an inescapable conclusion: there was no golden era of the jury trial, or if there was, it was a tarnished one. Thus if we are witnessing the "twilight of the adversary system", it is not at all clear when if ever there was a "high noon". To speak of "twilight" is to foster a myth of a nonexistent past. When trials were once extensively relied upon, they were, at least in the vast majority of ordinary offenses involving ordinary people as indicators by the two trials briefly discussed above, brief perfunctory affairs that bear but scant resemblance to the contemporary jury trial. In a very real sense, the very nature of what a trial is has undergone revolutionary changes to such an extent that comparisons across lengthy periods may not even be meaningful.

When jury trials were common, testifying at trial constituted the major, if not the only, opportunity the accused had to protect his interests. Without counsel, the accused did not know and thus could not invoke the rules of evidence or the right of confrontation, or know how to skilfully cross examine witnesses. Nor was the accused advised of his or her right to silence. The trial, without either a prosecutor for the victim or an attorney for the accused, was presided over by a judge who

12 Feeley (1978), supra n. 6, at 344. 
administered rough justice, and the defendant was largely dependent upon him for providing whatever protections were accorded. And without a lawyer to help, prosecutors stumbled through their charges. Although the committing magistrate and the grand jury had imposed some structure on the charges and order to the evidence, prosecutors remained heavily dependent upon the trial judge for help.

Furthermore, especially in England where, until well into the nineteenth century, all felonies were punishable by death, at trial the defendant was forced to blend a concern with (and strategy for) avoiding conviction, with a concern with and strategy for avoiding a capital sentence. The latter concern was often purchased at the expense of the former; in order to make a convincing case for mercy, the accused had to acknowledge - or at least not vigorously deny - guilt and marshal mitigating factors. This same catch- 22 continued even after the death penalty was abolished for most crimes in England, because other fixed penalties came to replace it. In the American colonies and later in the United States, penalties were never so harsh, but nevertheless they tended to be fixed and thus a function of the offense. So, in both places, defendants at trial had reason to merge their concern with maintaining innocence (or at least of denying guilt and hoping for acquittal) with a concern for offering mitigating factors and evidence of good character in hopes that the jury and judge would be merciful.

One of the central criticisms of modern plea bargaining is that it blends concern about guilt with concern about punishment in ways that undermine the integrity of the process. Yet, as we have seen, until courts separated the guilt phase from the punishment phase, these two concerns were merged and muddled together in the traditional trial as well. The modern trial system distinguishes between the guilt phase and the penalty phase of the process, and thus permits vigorous denial of guilt at the first stage, and acknowledgment of guilt at the second, sentencing stage. Although plea bargaining does conflate these two concerns, the accused in the modern plea bargaining process is at least represented by counsel who can negotiate these two different concerns. This suggests that the accused is still in a stronger position than in the eighteenth century jury trial, where the two issues were not separated and he or she was not represented by counsel. In this sense, the ability to negotiate a plea may represent an increased capacity to take part in an adversary process, in contrast to the earlier trial where the accused was largely dependent upon the judge for guidance and the jury for mercy. 


\section{The Lawyerization of the Process}

In a very real sense, the criminal trial in the eighteenth and early nineteenth century was an amateur affair. But as the criminal process professionalized, as lawyers for prosecutors routinely came to appear for the victim (earlier in North America than in England) and as counsel for the accused became more common, the nature and significance of the trial was radically transformed. Lawyers for prominent defendants and in celebrated cases in the eighteenth century had helped the courts develop sophisticated rules of evidence and procedure, but they were largely honored in the breach in ordinary cases where lawyers were not present. They only came to be invoked in ordinary trials when lawyers began to appear in substantial numbers. But when this occurred, the nature of the trial changed dramatically and so too did the proportion of cases going to trial. It declined markedly. In short, as the criminal process professionalized, as opportunities for the defense - and prosecution - expanded, reliance on the jury declined.

During the period under examination, English criminal process underwent two major transformations. First, the eighteenth century saw the establishment of the modern adversary process; lawyers developed the modern rules of procedure and evidence, and then in an increasing proportion of the cases, they came to represent prosecuting victims and then the accused. Both these new rules and the increase in the numbers of lawyers in routine - as opposed to extraordinary and celebrated trials led to the development of the modern trial process. These developments, in turn, led to a second transformation. As the trial became more complex, the lawyers who were coming to dominate it, developed an alternative. Ironically, just as the components of the modern jury trial were put into place, and the capacity to use them was developed, these very developments themselves undermined the process they were designed to enhance. As the trial came to be vigorous and complicated, its centrality and the prominent roles of the judge and jury began to wane, displaced by a lawyer-dominated guilty plea process.

John Langbein dates the beginning of the modern adversary system to the early eighteenth century. ${ }^{13}$ Until then, he maintains, judges

13 John Langbein, "The Criminal Trial Before the Lawyers", (1978) 45 U. of Chicago L.R. 263. See also John Langbein, "Shaping the Eighteenth Century Trial", (1983) 50 U. of Chicago L.R. 2. 
dominated felony trials. With enactment of the Marian committal statutes of 1554 and 1555, magistrates who had first heard felony charges laid against the accused were required not only to bind them over to crown court, but to prepare a statement of prosecution which was to be presented to the higher court. There the accused was presented to a grand jury, and if indicted, tried. Thus by the time the case came to trial, two judges had already reviewed the evidence. It is easy to imagine how judges, in the absence of lawyers for the parties, might continue to dominate this process at the jury trial.

Despite Bushel's case in 1670 , which is celebrated as a symbol of the independence of English juries, ${ }^{14}$ judges in fact continued to dominate juries for many years to come. In the vast majority of ordinary criminal cases the judge was the only law-trained person in the courtroom, and may have presided over the grand jury that had indicted the accused. Under these circumstances judges could refuse to accept the verdict of the jury if it displeased them, force the jury to reconvene to reconsider its verdict, dominate the questioning of parties and witnesses, and terminate proceedings which were not going well. Above all, in the absence of lawyers for the parties, juries were dependent upon the judge for guidance.

Two developments in the mid eighteenth century affected the increase in the presence of lawyers in ordinary cases. In 1752, Parliament authorized judges to order local governments to reimburse victims of selected offenses for the cost of their prosecution, in effect providing a rudimentary legal aid scheme. At about the same time, lawyer-entrepreneurs seeking to expand business, began to solicit merchants to subscribe to prosecution societies, insurance schemes which guaranteed victimized members the full cost of prosecution. Both of these developments significantly increased the likelihood that lawyers representing prosecuting victims would be involved in the criminal process. No doubt the availability of lawyers for prosecutors spurred the growth of lawyers for the accused as well. Whatever the case, beginning in the 1730s laws limiting the role of lawyers for defendants felony cases began to be relaxed for those who could afford them, and lawyers began to advise the accused, address the court on matters of law, and examine witnesses. ${ }^{15}$ However it was not until a century later, in 1836, that lawyers

14 Bushel's case denied judges the power to fine jurors who brought in verdicts unacceptable to them.

15 Langbein (1978), supra n. 13, at 265. 
for the defense were allowed to address the jury directly in felony cases. This steady growth of the role of lawyers, coupled with an tradition of private prosecution and an adversary theory that emphasized party domination of the process, led to a slow but steady shift away from judge-dominated to lawyer-dominated proceedings.

Although the developments that led to this shift were initiated in the eighteenth century, it was not until well into the nineteenth century, that they show a marked impact on the criminal process in ordinary cases. My sample of criminal cases taken from records at The Old Bailey from 1687 to 1912 (see Figure 1), reveals a marked absence of lawyers throughout the 1700 s and well into the 1800 s, and that a dramatic increase of lawyers occurred only in the mid-nineteenth century.

Despite the slow pace, the eventual lawyerization of the criminal process had far-reaching consequences. Figure 1 charts the steady increase in lawyers for both the defense and prosecution between 1687 and 1912. The beginning and end of this long period is a study in contrasts. From the late seventeenth century until mid-nineteenth century, lawyers only occasionally appeared, either for the prosecution or for the defense. However by the early twentieth century, it was routine for lawyers to represent both the prosecution and the accused. ${ }^{16}$ As I show below, this growth parallels the development of the elaborated jury trial, which in turn foreshadowed the decline in the frequency of the jury trial.

\section{The Decline of the Role of the Jury: A Quantitative Overview}

One of the traditional defenses of the jury is that it serves as a restraint on authority and thus assures that administration of justice will remain in at least rough accord with popular sentiment. There is no doubt that juries at The Old Bailey served this function. Indeed during a period when almost every felony was punishable by death, as

16 We recognize that the figures in Figure 1 understate the importance of lawyers in the criminal process. From other sources we know that at times they were retained to help victims bring prosecutions and to advise defendants how best to respond, even though they did not appear at trial. And, as we shall see, in cases where defendants plead guilty lawyers may have played a role that was not recorded. Still these figures are useful in providing an indication of the active presence of lawyers in proceedings during the period under consideration. 


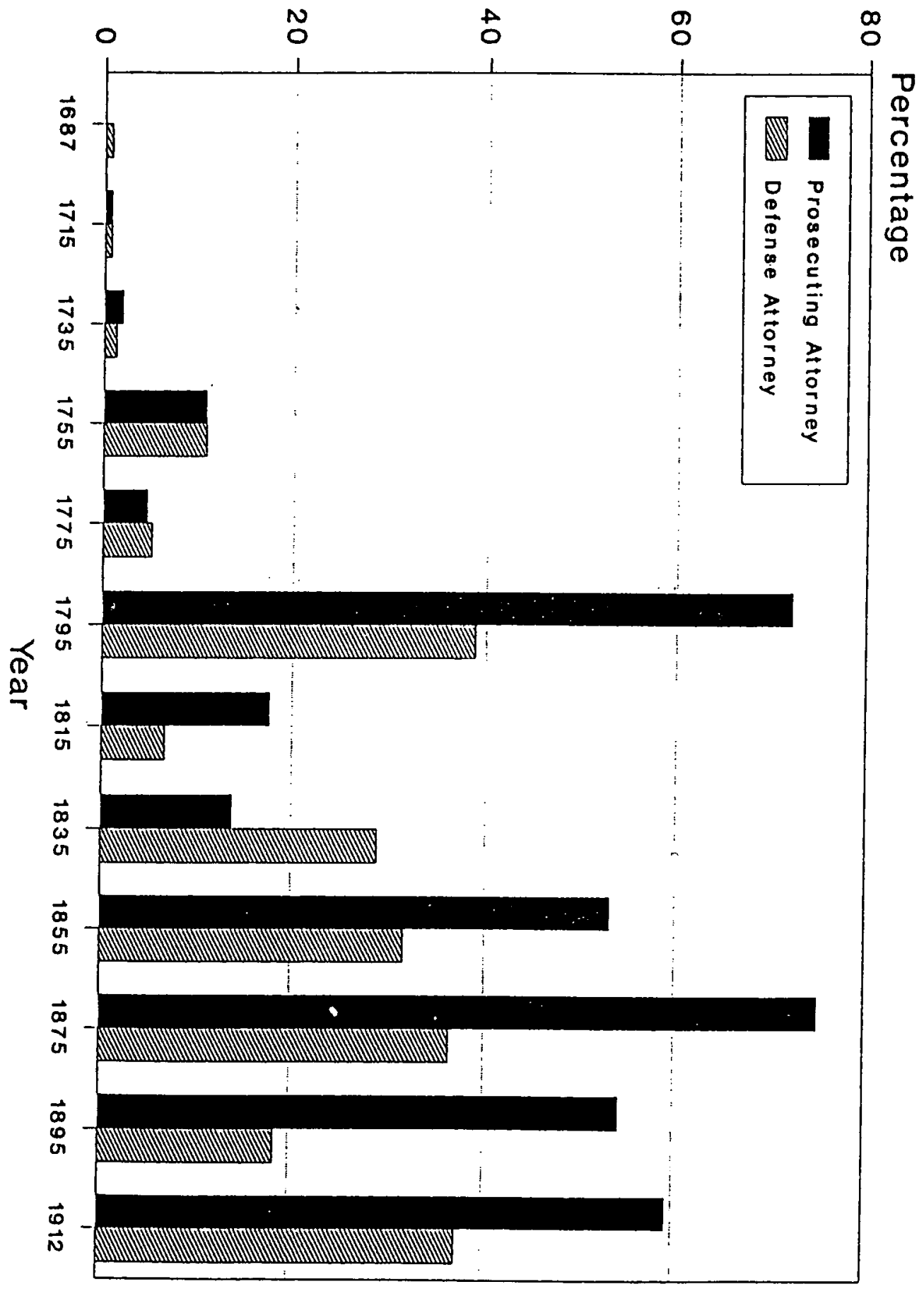

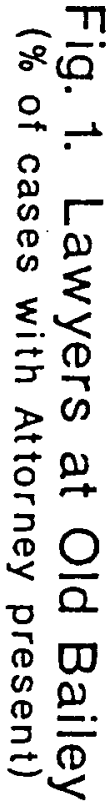


was the case in England well into the nineteenth century, one of the major functions of The Old Bailey juries was to ameliorate the harshness of the law by refusing to convict some obviously guilty defendants, convicting others on reduced charges, and petitioning the crown for mercy after convicting still others. While it is impossible to estimate the full extent of these practices, it is possible to provide some indication of the shifting magnitude and importance of these ameliorating practices. Figure 2 reports on the percentage of cases in which juries acted "independently", i.e. brought in "partial verdicts" of guilt on reduced charges, or reduced the value of stolen items and convicted on lesser offenses, or convicted and recommended mercy. Identified in this manner, the decline of the importance of jury "independence" is both marked and rapid. Throughout the early eighteenth century, The Old Bailey acted "independently" in almost half of all cases, but then the proportion declines quite rapidly.

From 1687 until 1775, almost all of this jury "independence" is accounted for in terms of jury resistance to capital punishment (and later transportation) in cases involving thefts of small amounts. Typically in such cases the jury would return a verdict of guilt, but value the items just below the felony-level threshold. As these punishments for theft were curtailed, so too was this practice by the jury. Still, for whatever reasons, Figure 2 does reveal a steady decline in the role of the jury as "independent" force in the administration of criminal justice.

Another indicator of the relative decline in the importance of the jury is seen in the shift in the mode of disposition. Figure 3 shows the nature and extent of this change. It reveals a steady decline in reliance on juries and correspondingly a marked increase in guilty pleas, a process which by-passes altogether introduction of evidence, examination of witnesses, and jury deliberation. Until 1835 juries disposed of between $95 \%$ and $98 \%$ of all cases, and the occasional case not decided by a jury usually was handled by a judge who directed acquittals or dismissed cases for nonappearance of the prosecutor. By 1835, however, a new form of disposition was introduced; in that year six percent of the cases were disposed of without a jury trial, by pleas of guilty. After that reliance on the guilty plea grew steadily, until around the turn of the century it accounted for around $40 \%$ of all dispositions. ${ }^{17}$ As the practice

17 It continued to grow throughout the twentieth century. At The Old Bailey as elsewhere, now trials are the rare exceptions and not the rule. 


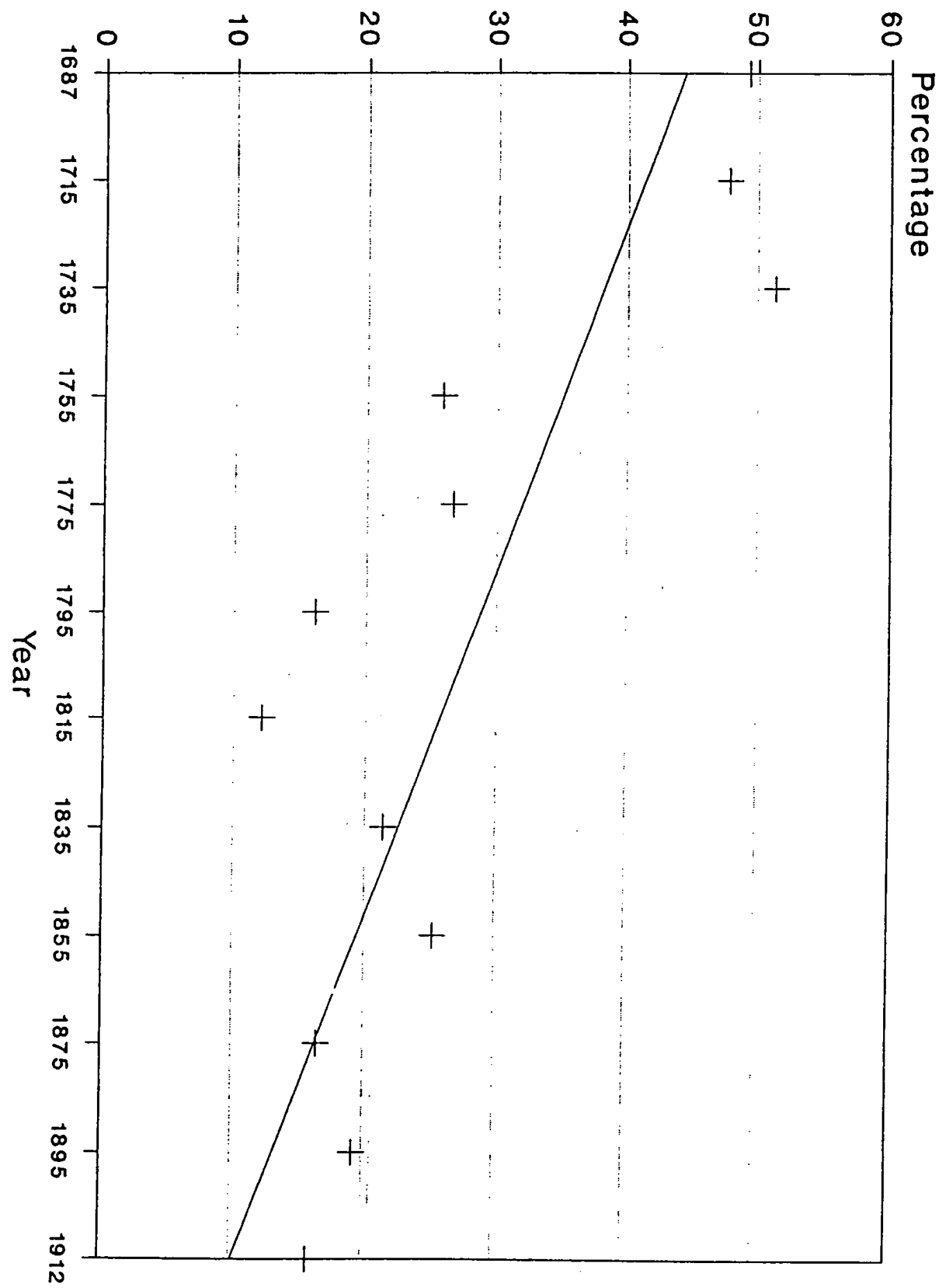

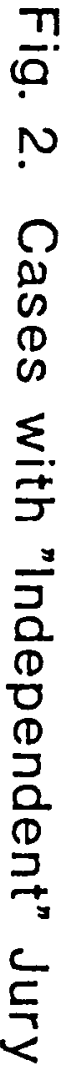


grew it also became more differentiated; beginning in 1835 we see a handful of defendants pleading guilty to reduced charges (3\%), and this mode of disposition grew steadily throughout the balance of the period. By 1912, it reached eight percent or nearly one fifth of all guilty pleas. And since then, this trend has accelerated. ${ }^{18}$

This new type of guilty plea to reduced charges suggests still another innovation in the felony justice system, plea bargaining, where the accused shifts his plea of not guilty to guilty in exchange for an agreement to reduce charges. Although these figures alone do not describe this practice, they do suggest it.

The figures in Figure 3 showing the growing numbers of guilty pleas and pleas to reduced charges do not capture the full extent in the decline of the importance of the jury trial. This steady decline of trials in crown court must be seen in the context of a series of Parliamentary acts which reclassified numerous felonies as misdemeanors, and redirected vast numbers of cases from crown courts to magistrates courts for summary (nonjury) disposition, usually by means of a guilty plea. For example, the Summary Jurisdiction Act of 1855 granted magistrates the power to summarily try cases previously within the exclusive jurisdiction of the crown courts, including simple larceny where the value of goods did not exceed five shillings. Several such acts throughout the nineteenth century substantially reduced the jurisdiction of crown courts and thus removed a vast number of offenses from the reach of the jury. Were these cases to be included in this analysis of the rise of the guilty plea process, the decline of the jury and the rise of the guilty plea and plea bargaining would be even more dramatic than is indicated by only those cases which remained within the jurisdiction of The Old Bailey.

Some of the new laws transferring jurisdiction, created "hybrid" offenses which could either be tried by jury in crown court or summarily in magistrates court. The ways these offenses were prosecuted strongly encouraged the accused to plead guilty in magistrates court rather than face more serious consequences if convicted by a jury in crown court. Indeed some of these laws specifically provided for lesser penalties if the

18 See e.g. John Baldwin and Michael McConville, Negotiated Justice: Pressures on Defendants to Plea Guilty (1979) 18. 

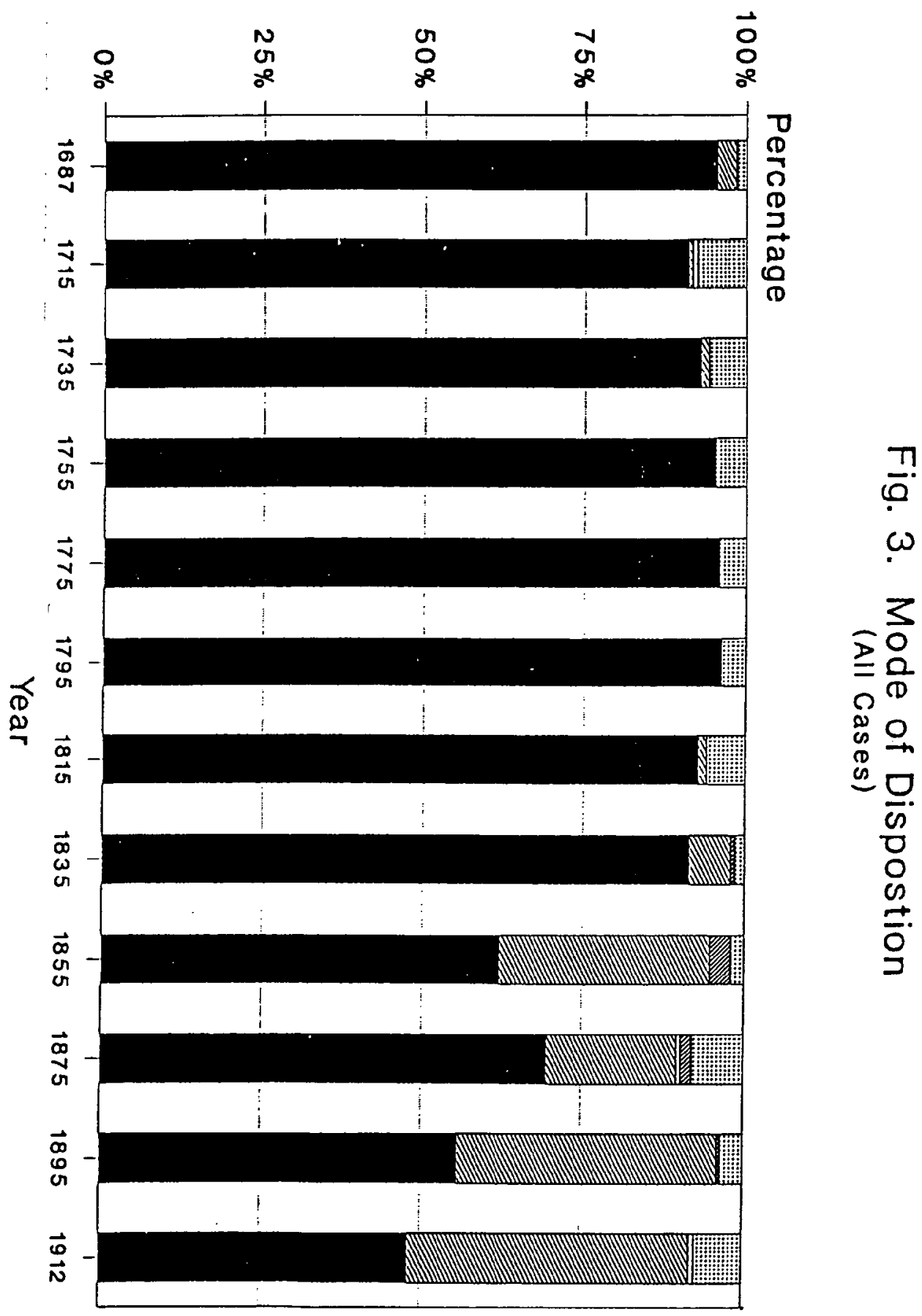
accused agreed to plead guilty in the lower court and waived right to a jury trial in crown court. ${ }^{19}$

Thus the observed decline in trials shown in Figure 3 is only the proverbial tip of the iceberg; it must be seen against the cumulative effect of the expansion of summary jurisdiction of magistrates which removed to magistrates' court a huge portion (perhaps as much as seventy five percent) of offenses that once were triable by juries. Were it possible to combined these two sets of offenses - those triable in crown court and those once triable but removed to magistrates court one would see a much steeper increase in the proportion of cases resolved by guilty pleas and an even more dramatic decline in the role of the jury. Together these two changes - increased guilty pleas in crown court (Old Bailey) and the shift of many offenses to magistrates court for summary handling (usually through guilty pleas) - constituted a revolutionary shift in the mode of disposition of cases in the criminal process. By the end of the nineteenth century, the English jury had been stripped of three quarters or so of its jurisdiction in criminal matters, and a growing number of those cases that did remain within its jurisdiction were in fact being resolved by guilty pleas. Increasingly the jury, cabined by strict rules of evidence and procedure, was displaced by lawyers who resolved matters themselves, and called upon the judge merely to ratify the decision, or was explicitly eliminated and replaced by summary proceedings. ${ }^{20}$

I do not mean to suggest that the jury had lost all its autonomy by the beginning of the twentieth century. Indeed, when it continued to act during the nineteenth century, it was vigorous and powerful. This is suggested by the steady rate of not guilty verdicts (Figure 4) throughout the entire period under examination. Despite the fact that increasingly cases were reviewed by lawyers prior to trial (which could lead to charges being dropped or guilty pleas), roughly the same proportion of cases that were tried by a jury resulted in a not guilty verdict throughout the entire period. If anything, these figures suggest that the relative importance of the jury trial may have increased over time.

19 For a history and description of the many new sentencing laws in the late eighteenth and early nineteenth century, see Sir Leon Radzinowicz, A History of English Criminal Law and its Administration from 1750, vol. 1: The Movement for Reform (1948).

20 For a discussion of the way in which this is done in contemporary English courts, see Baldwin and McConville, supra n. 18, at 39. 


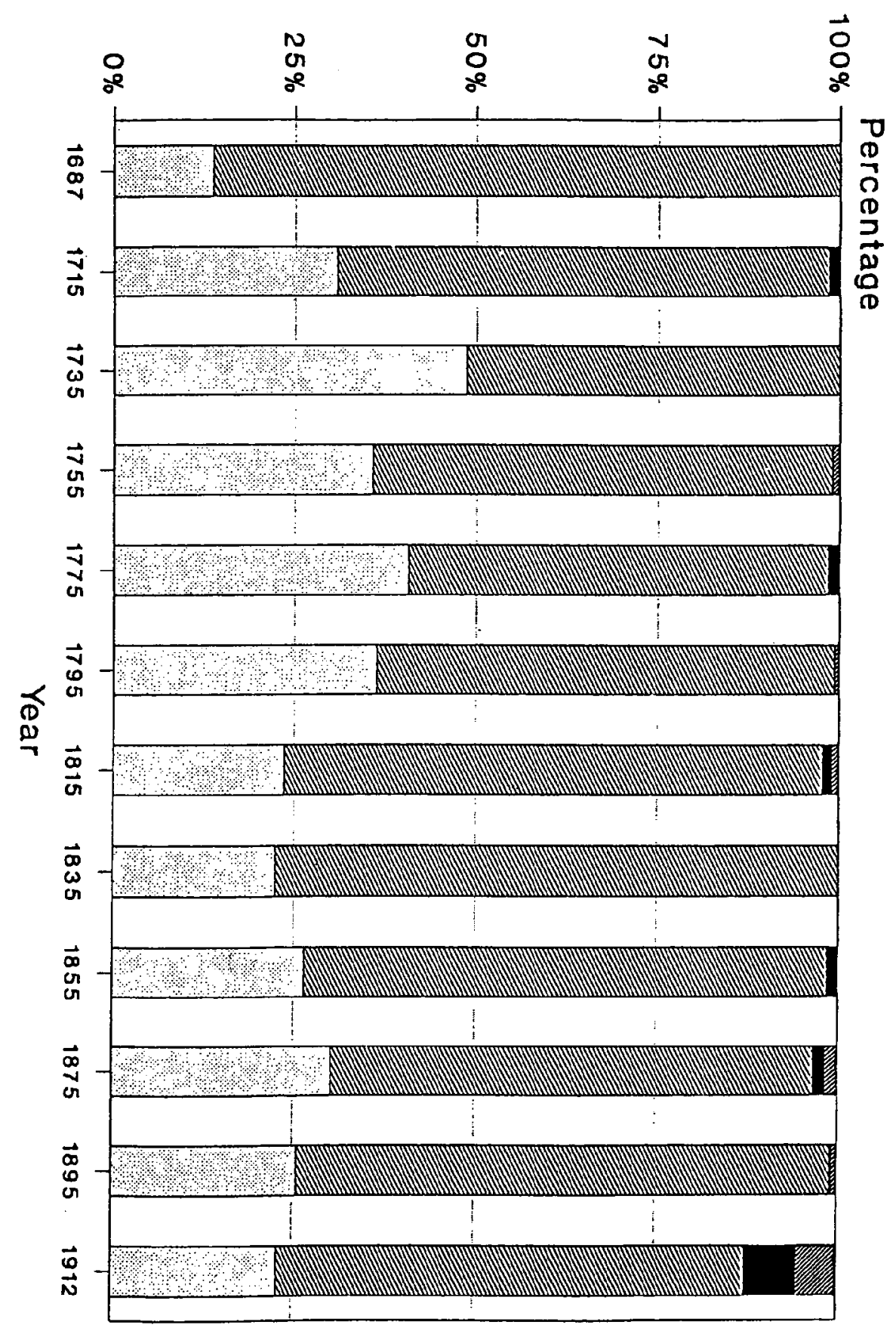

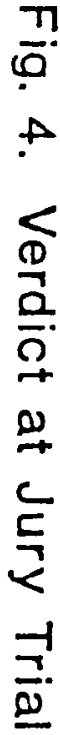




\section{Causes of the Bifurcated Process: Jury Trials and Guilty Pleas}

So far I have focused on the declining role of the jury and the emerging importance of lawyers. The data, reported earlier reveal that throughout the latter part of the eighteenth century and the nineteenth century, the jury was largely displaced by guilty pleas and summary proceedings in magistrates courts. In this section I focus in greater detail on the nature of the jury trial in order to shed light on the emergence of guilty pleas and plea bargaining. In brief, my argument is that as the role of lawyers in the criminal process increased, the jury trial became more complicated. This in turn led to fewer but longer trials, on the one hand, and quick pleas of guilty and plea bargaining, on the other. As discussed in the previous section, many cases were redirected to magistrates court where they were dealt with summarily (often by pleas of guilty). But even of those that remained in crown court, fewer and fewer went to trial as lawyers came to dominate the process. The growth of the presence of lawyers created a two-track system: A decreasing number of cases were handled by increasingly complicated jury trial, and an increasing number of cases were disposed of in a rapid process of guilty pleas and plea bargaining dominated by lawyers. This section shows in some detail how as the jury grew in complexity, it came to be used less frequently. Figures 5-10 examine various aspects of this development.

\section{The Increasing Length of Trials}

Although there are no consistent and reliable measures of the average length of time trials took throughout the period under examination, one good indicator is the number of trials a judge (and often the same jury) handled in a single day. Figure 5 reports on the average number of trials handled by a single judge (and jury) per day. In the late seventeenth century and well into the nineteenth, a single judge and jury heard on average over four cases per day. But by 1912, the average was less than one case per day. Thus there was more than a four-fold increase in the length of time it took to complete a trial. Although this shift is halting, it is steady and substantial. ${ }^{21}$ The question is why and

21 Figure 5 shows only the average number of trials per court per day, but it is important to realize that the increase over time is not simply a consequence of the increase in guilty pleas. Until the 1850 s virtually no trials lasted longer than half a day. By the end of the century, a substantial portion lasted longer than one day. 


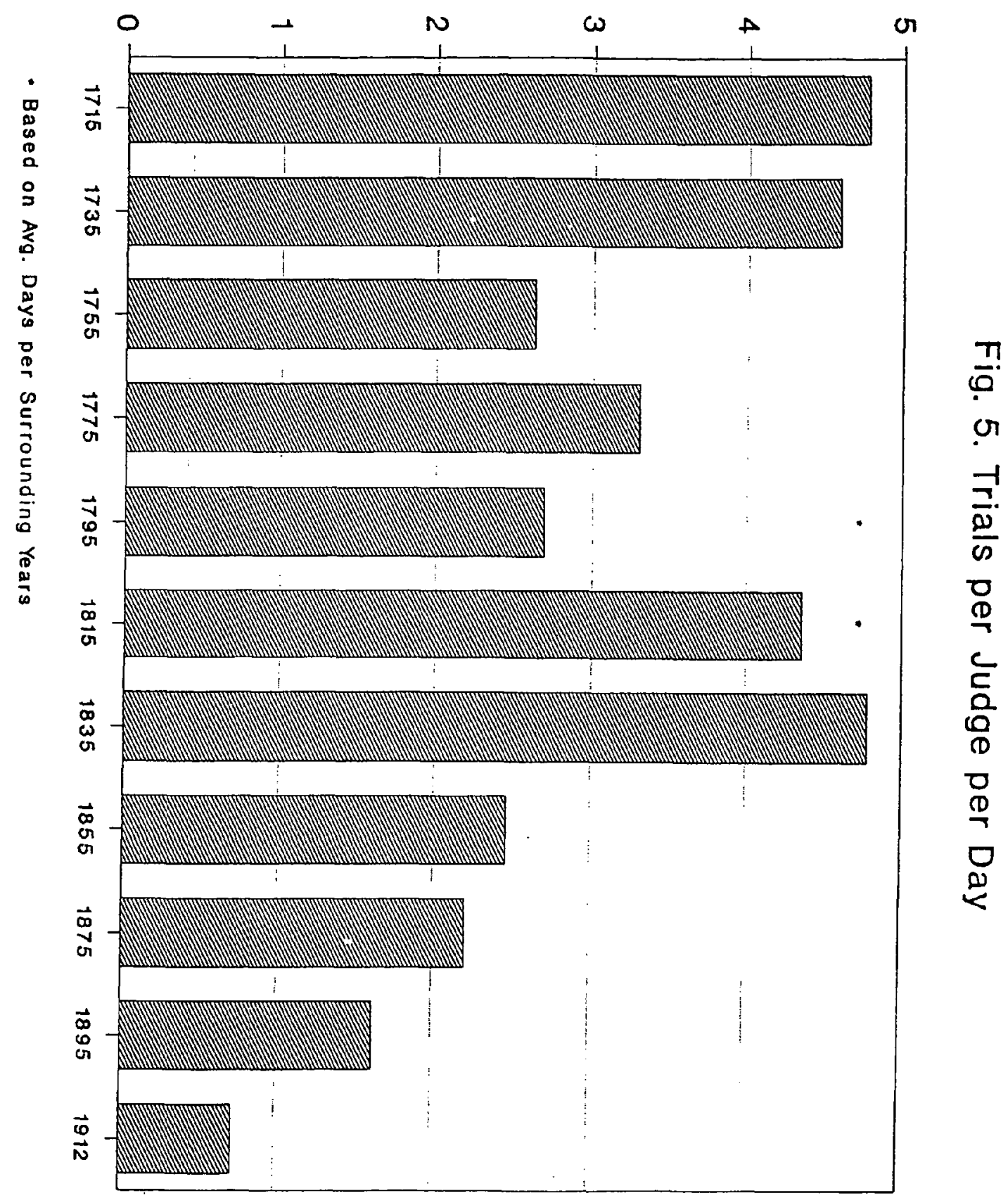


how did the trial come to be complicated and lengthened? My analysis accounts for these changes largely in terms of the impact of innovations introduced in the eighteenth century - the hearsay rule, various procedural innovations, the expanded role of lawyers for the defense, and the increased support for the prosecution, and the like - but which remained dormant in all but the exceptional cases until lawyers began to appear for the prosecution and the accused in substantial numbers, something that did not occur until nearly one hundred years later in the mid-nineteenth century.

Figure 5 does not support the view that guilty pleas and plea bargaining is a result of increased case load pressures, as least as the argument is conventionally expressed. ${ }^{22}$ Although we see a steady decline in the proportion of jury trials and a corresponding increase in guilty pleas, nothing in this shift suggests that guilty pleas came to displace careful, adversarial, and deliberate jury trials. Up until and throughout most of the nineteenth century, the vast majority of jury trials were rapid perfunctory affairs. It was only with the coming of the lawyers and the bifurcation of the disposition process (i.e. some lengthy jury trials and many more short-order guilty pleas) towards the end of the nineteenth century that the jury trial emerged in its modern form - lengthy, complex, complete with examination and cross-examination of witnesses, dominated by aggressive lawyers, and the like. But this development occurred only after large numbers of offenses had been redirected to magistrates court and caseload pressures on the crown court (The Old Bailey) may in fact have decreased. Although procedural and evidentiary innovations could complicate and lengthen the jury trials, by themselves they had little impact on the overwhelming numbers of ordinary cases. It is only with the increase of lawyers in large numbers that substantial changes occurred. They created the new elaborated trial process and then came to dominate it. But at the same time, they instituted another process, reliance on the guilty plea. And they came to dominate it as well. It is in this sense that the modern jury trial and the modern plea bargaining process emerged simultaneously. The latter did not replace the former.

Ironically, this suggests there may be more continuity in the criminal process than at first appears. Indeed Figure 5 suggests that there never was a "golden era" of the jury trial before plea bargaining. Just as the 
careful, deliberate trial began to develop (as indicated here by its length), it ceased to be used with such frequency, and indeed rapidly fell into decline (a decline which has accelerated in the twentieth century as the role of lawyers in the process has continued to expand).

\section{The Development of the Modern Jury Trial}

The preceding section revealed the emergence of a bifurcated criminal process beginning in the late nineteenth century. This section examines that development in more detail. In particular it explores how the jury trial developed, why a bifurcated process - increasingly lengthy jury trials and rapid guilty pleas - emerged, and how the two are related. I will show that the changes are related to several factors, including the: 1) increased use of lawyers at jury trials; 2 ) increased use of expert witnesses; 3 ) increased concern with evidence and procedural rights; 4) increased vigor of defense (as indicated by increased use of cross examination); and 5) decline in the use of character witnesses by the defense and increased use of evidentiary witnesses by the prosecution (Figures 6-11).

The section concludes with an analysis of a Legal Complexity Index (LCI), which provides a summary indicator of "adversarial vigor", and then relates it to the proportion of jury trials (Figure 11). Perhaps more clearly than any other indicator, the LCI shows that just when the jury trial developed as a vigorous adversarial institution, it was replaced by the guilty plea process.

\section{Increased Presence of Lawyers at Trial}

Earlier I examined the growing role of lawyers in the felony process. Here I explore this role in more detail. The most basic consideration is, of course, whether lawyers were present at trial. Figure 6 reports on the proportion of trials at which the prosecution and defense were represented by lawyers. It reveals that until the early to nineteenth century neither the prosecution nor the accused was usually represented by a lawyer (1795 constitutes something of an anomaly), but by the latter half of the nineteenth century the proportion of trials in which lawyers represented one or both parties had increased considerably. By the end of the nineteenth century, lawyers generally appeared in trials. Well 

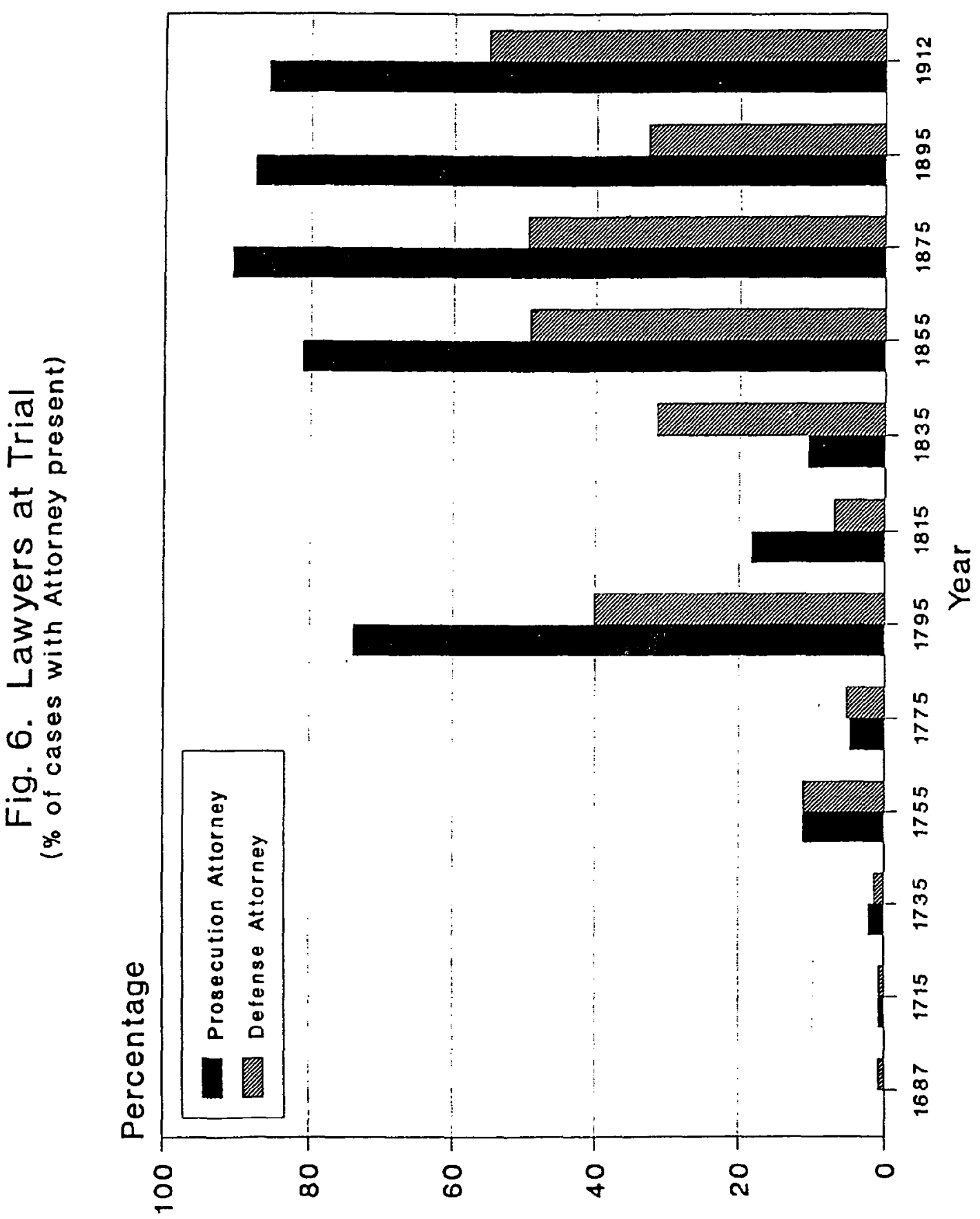
over half of the accused were represented by counsel, and ninety percent of the prosecutors were represented.

\section{Developments in Evidence}

Revisionist historians of evidence locate the origins of the modern rules of evidence used in ordinary criminal cases in the mid-eighteenth century, following the entrance of lawyers into the process..$^{23}$ No doubt this is correct; although refined arguments about the introduction of certain types of evidence were debated in the occasional state trial as early as the seventeenth century, such arguments were not heard in "ordinary criminal cases, such as those presented at The Old Bailey", until the middle of the eighteenth century. However, even this development had but scant if any impact on the conduct of the ordinary trial until well into the nineteenth century when lawyers began to appear in substantial numbers. This section traces changes in the use of evidentiary and procedural devices over time. The analysis yields two important findings: first, despite developments in the complexity of the rules of evidence in the eighteenth century, ordinary criminal cases were largely unaffected by these developments until well into the nineteenth century. Second, changes emerged only when lawyers came to be involved in substantial numbers of ordinary cases. When this finally occurred, the consequences were dramatic; the presence of lawyers completely changed the nature of the jury trial, turning it from an amateur affair into the highly choreographed and "artificial" process with which we are familiar.

As will be readily apparent, my discussion is not a comprehensive examination of evidentiary and procedural innovations during the eighteenth and nineteenth centuries. Rather it relies only on a few factors which are intended to outline the rise of the modern criminal jury trial. Put bluntly, as the criminal trial was professionalized - in terms of reliance on technical rules of evidence and procedure and reliance on lawyers to represent parties - the process changed dramatically. It became more complex and expanded in length. The nature, number, and types of witnesses changed. And almost simultaneously, it ceased to be used as frequently as the traditional jury trial had been. In short, just as the modern adversarial trial developed, so too was its alterna- 
tive, the guilty plea process. As suggested earlier, my analysis does not constitute a comprehensive narrative history of this transformation. Rather it presents something of a schematic diagram of the development, highlighting indicators of adversariness that illustrate the changes and showing their connections. The analysis then relates these factors to shifts in the length and frequency of the jury trial. The indicators are: 1) the use of expert witnesses at trial; 2) the introduction of evidentiary and procedural issues at trial; 3) cross examination of witnesses by defense; 4) shifts in the types of witnesses called, i.e. from character to evidentiary witnesses, and shifts in the number of witnesses for the prosecution. Although the discussion of each of these indicators is brief, the analysis reveals the simultaneous rise of these indicators of adversariness and the guilty plea process that is both powerful and convincing. This will become more evident in the last part of this section, where a single Legal Complexity Index (LCI), constructed from these several variables, is related to the rise of the modern jury trial. In sum this discussion reveals that despite their introduction in the mideighteenth century, these procedural and evidentiary innovations had little impact in ordinary cases until they were joined, in the latter part of the nineteenth century, by the presence of a substantial number of lawyers. But when they came to be used routinely, they had a dramatic effect on the nature and frequency of jury trials. Trials quickly became more complex and took longer to complete, but at the same time, they ceased to be used so frequently.

Expert witnesses. A famous commentary on seventeenth century England characterized the jury trial as a brief "altercation", in which the parties came together to have the judge and jury settle the matter. However, once lawyers entered the process in large numbers, they imposed revolutionary changes on the process. One indicator of this change is the increased sophistication with which evidence was presented at trial. One simple measure of this development is reported in Figure 7, which traces the use of expert witnesses in jury trials over time. Throughout the period under consideration, expert witnesses were the rare exception, although they did come to be used with much greater frequency towards the turn of the nineteenth century.

Three features stand out in Figure 7. First, throughout most of the period under consideration, expert witnesses were rarely used by the accused. Second, prosecutors began to use them with some regularity only in 1856 , and then in only between sixteen and twenty eight percent 


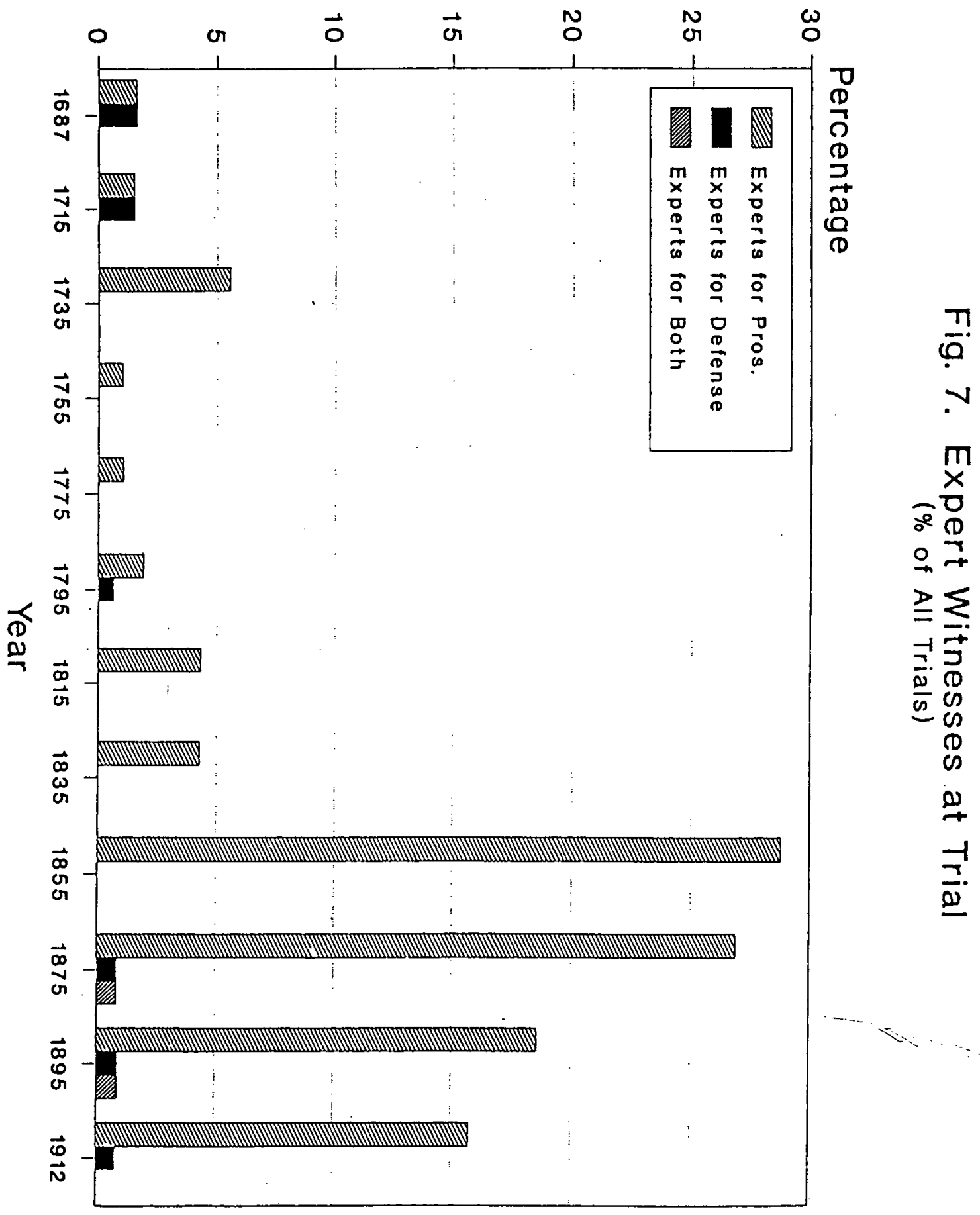


of all trials. Third, there was a dramatic increase in use of expert witnesses in the latter half of the nineteenth century. As will be seen, these developments closely followed the rise of the use of lawyers at trial.

Changes in rules of evidence and procedure. Another and perhaps more important indicator of the increase in the complexity of the criminal process is the frequency with which issues of law were raised by either the accused or the prosecutor. Issues raised under this heading range from challenges to the propriety of the indictment, to the jurisdiction of the court, to the applicability of a particular statute. As is seen in Figure 8, here too, there is a dramatic contrast between the first two thirds of the period ( 1687 to the 1855) and the latter period. Very few matters of law were raised until 1855; after that, there was a dramatic jump.

This is not to say that there were no matters of law raised by the defense in the earlier period. Indeed, in the Great Barrington Trial of 1789 , one of the cases in my sample, lawyers raised a number of issues of evidence and trial procedure, and they were considered at some length by the court. However, it was an exceptional case. Mr. Barrington was a man of high repute and income. And unlike the overwhelming majority of other defendants, he was defended by an able lawyer who made extensive use of objections to the questions put to the jury and to evidentiary matters. Indeed, Barrington himself challenged the jury and was successful in having it replaced by another one. This effort paid off: Barrington was found not guilty. Still, although this trial does reveal the acceptance and use of various sophisticated rules, it nevertheless is distinctive, and is not representative of ordinary criminal cases of the times. Indeed, it was not until well into the nineteenth century, that we find any of the issues of this case raised with any regularity in "ordinary" criminal cases.

Cross examination by defense. The conventional image of the adversary process envisions two advocates vigorously arguing their cases before a neutral and largely passive judge. Their task: present their clients in the best possible light and to point out weaknesses of their opponents. However this image bears only scant resemblance to practices in the trials during the first half to two thirds of the time span covered in the sample. The rare exception of the Great Barrington Trial notwithstanding, the typical defense until well into the nineteenth 

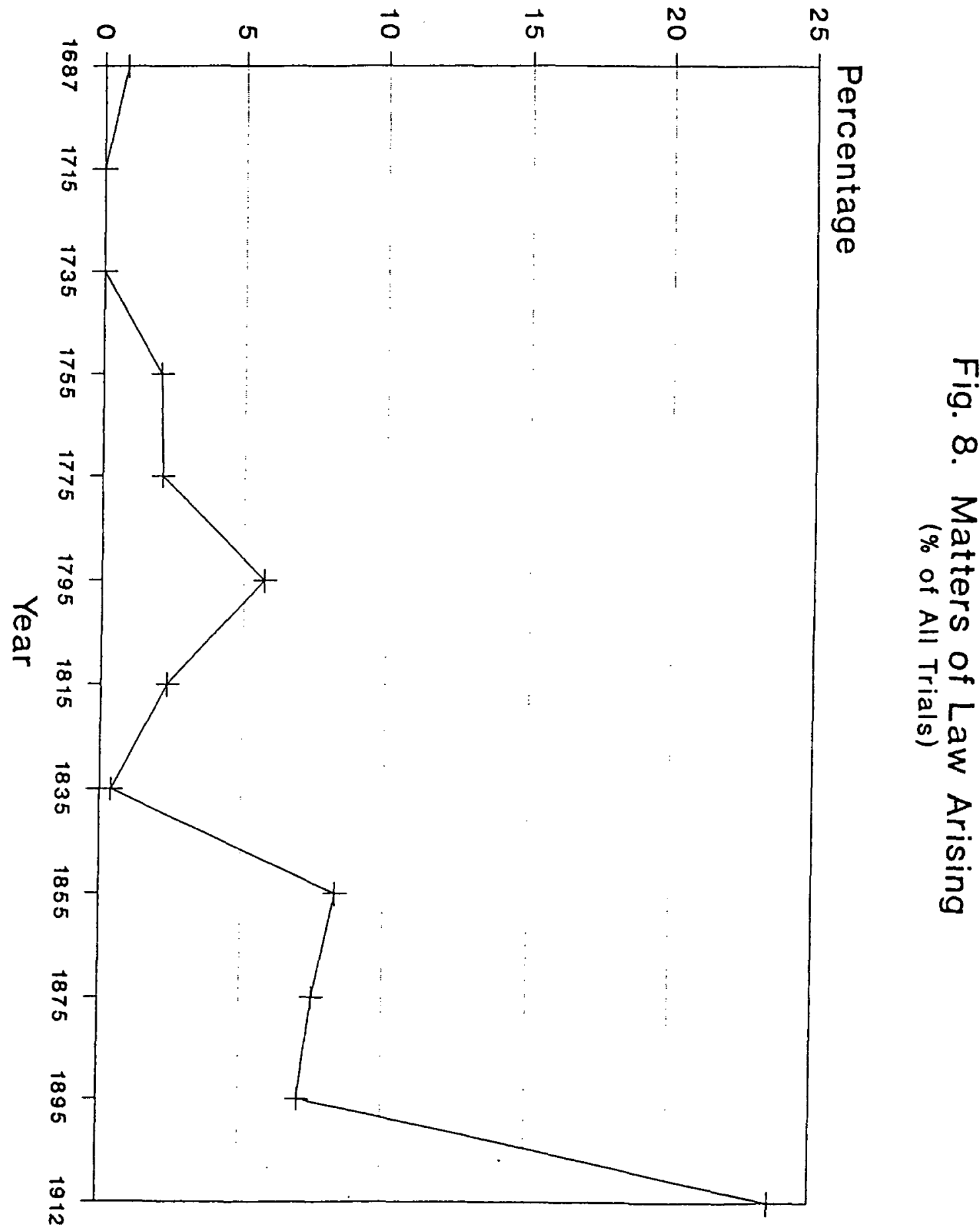
century consisted of little more than a plea for mercy, testimonials of good character by witnesses for the accused, and the occasional lame or unsubstantiated excuse such as "I found it" or "someone gave it to me". Although there is a steady increase in the use of cross-examination, the slope of the regression line in Figure 9, is somewhat misleading. A closer look reveals that much of this steady increase is a result of the high figures for only one sample year, 1795. Apart from this "anomaly", however, cross examinations were uncommon until 1835 , when rather suddenly their use increased to 45 percent of all cases. After 1855 , they showed another marked increase, from between sixty and seventy percent of all trials. In sum, as measured by this indicator (apart from 1795) suggests that there were few vigorous adversarial defenses until the mid- nineteenth century.

Testimony by "character" and "evidentiary" witnesses. My data indicate that the eighteenth century certainly did not lack witnesses for the accused. Indeed the accused introduced somewhat more witnesses during the eighteenth and early nineteenth centuries than during the middle and latter part of the nineteenth century. But there is a striking difference in the witnesses in these two periods. Throughout the eighteenth century and well into the nineteenth, the accused were much more likely to rely on witnesses to testify to good character; from midnineteenth century, they called character witnesses-much more sparingly and came to rely heavily on evidentiary witnesses. This is still another indication of the emergence of a vigorous adversariness, but again one that emerged towards the end of the nineteenth century.

This shift - a decline in character witnesses and an increase in evidentiary witnesses - is one more indicator of an important transformation of the criminal trial. Earlier I suggested that the eighteenth century jury trial was in fact something like a modern-day sentencing hearing in that both proceedings tended to merge matters of guilt and punishment. Figure 10 reinforces this assertion. It was not until 1895 when defense witnesses contradicting the prosecution's account of the facts began to appear in large numbers (and the proportion of character witnesses declined). In contrast, the earlier reliance on the testimony by the accused which requested mercy, or of witnesses who testified to good character suggests that the aim of the trial - from the accused's perspective - was not to challenge the facts or the charges, but to call mitigating factors to the attention of the judge and jury in hopes of a lesser penalty. In this sense the traditional jury trial bears striking 

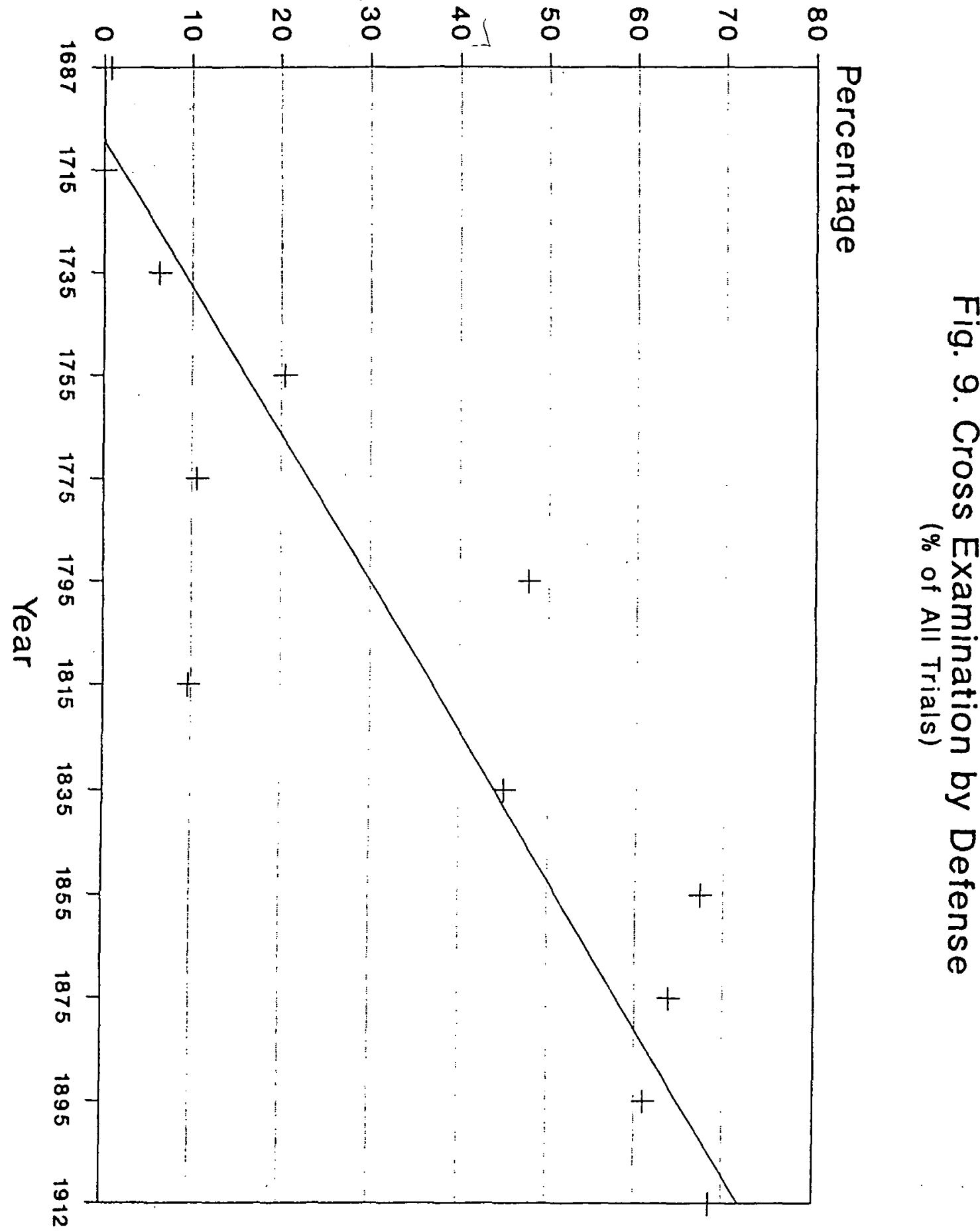


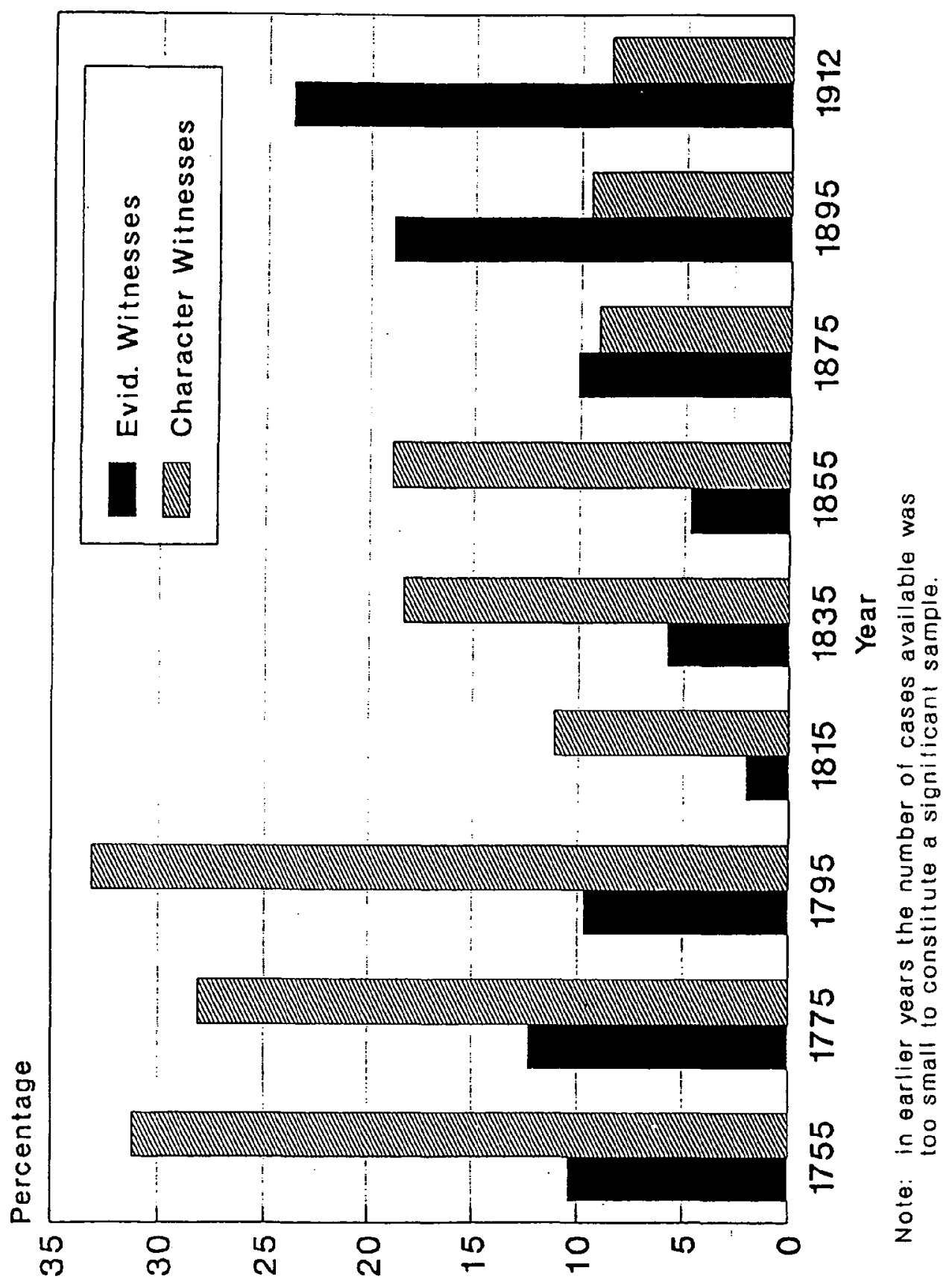


resemblance to modern plea bargaining; both processes merge consideration of guilt and consideration of punishment in ways that the modern jury trial does not.

\section{Legal Complexity and the Decline of the Trial: A Summary Indicator}

So far I have examined each of several indicators of legal complexity and adversariness independently, showing how each increased over time. In this section I aggregate them in order to explore my central thesis, that as the modern adversarial jury trial developed, it undermined itself, and fostered use of the guilty plea. That is, as efforts to improve the trial's fairness and accuracy proved successful, they also increased its complexity, and this in turn led to the development of an alternative, but one created by and controlled by the lawyers. The Legal Complexity Index (LCI) provides a single summary indicator of "adversariness" whose variation can be related to changes in the proportion of cases handled by jury trials. The findings support my central hypothesis: as adversariness increased, jury trials decreased and guilty pleas increased. (See Figure 11.)

The LCI is constructed from several of the factors discussed in the preceding section, and relies heavily on Lon Fuller's famous definition of the adversary process: ${ }^{24}$

The essence of the adversary system is that each side is accorded a participation in the decision that is reached, a participation that takes the form of presenting proofs and arguments. If that participation is to be meaningful it must take place within an orderly frame, and it is the duty of the judge to see to it that the trial does not degenerate into a disorderly contest in which the essential issues are lost from view.

Obviously Fuller's conception of the adversary process, spelled out in numerous articles and papers, is richer than can be captured in these two sentences. And certainly it is richer than can be "operationalized" by a set of readily available "indicators" from my sample of cases from The Old Bailey. Nevertheless, as I have shown, these indicators do

24 Lon Fuller, "The Adversary System", in Harold Berman, ed., Talks on American Law (1961) 41. 

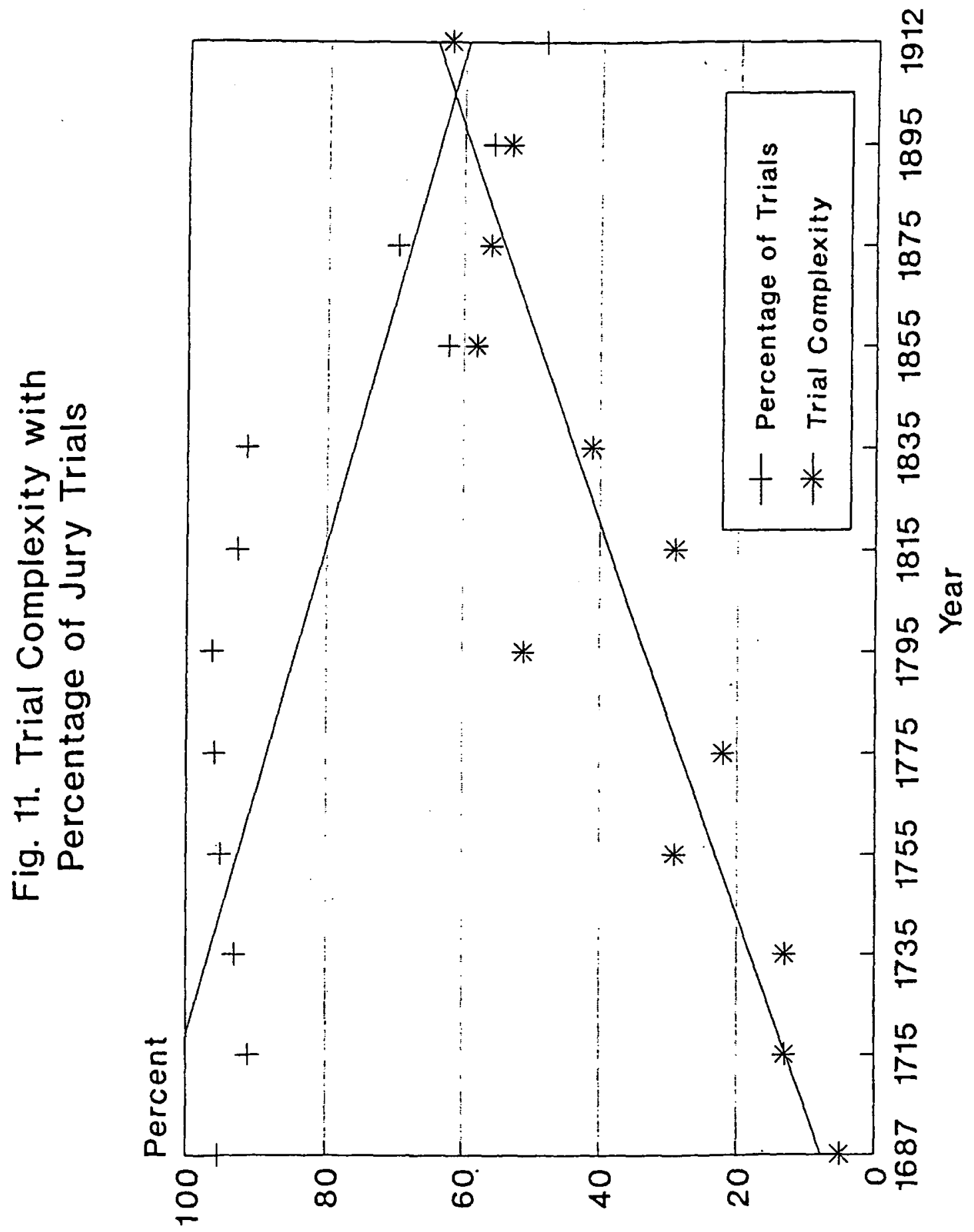
reveal marked and important developments in the nature of the criminal trial in ways that provide a crude but nevertheless useful moving portrait of the trial over time.

The LCI represents the sum of seven variables that may themselves by viewed as one or another of the indicators of Fuller's three conditions. These variables, most of which have already been introduced in the discussion, are: the presence of 1) prosecution attorneys, or 2) defense lawyers, 3) the vigor/complexity of prosecution and 4) defense, 5) the use of expert witnesses, 6) whether either party raised questions of law, or 7) questions of evidence or procedure. ${ }^{25}$

25 I experimented with various ways to assign values to each of these indicators. In general, they made little or no difference in the outcome, since all I am trying to do here is to show the general affinity between the growth of the use of adversarial techniques and the decline of the use of the jury trial. Generally, the process I have used is easily understood and intuitively plausible. The presence of attorneys is straightforward. A case with no attorneys would not contribute value to the LCI variable, a case with one attorney would contribute the value 1 , and a case with attorneys on both sides would be scored as 2 . Thus, the more adversarial the proceedings - along these admittedly limited but nevertheless useful indictors - the higher the value.

The vigor or complexity of both prosecution and defense also posed a challenge since it was possible to construct this variable from diverse factors that had been coded. For instance "indictment dismissed" could indicate highly successful defense or especially weak prosecution. Ultimately we coded such values as " 0 " and wholly excluded them when creating the LCI indicator with "all controls". Hence the value of vigor or prosecution is 1 , only in those cases where either the defense was crossexamined or evidentiary witnesses were utilized. A value of 3 was given to those cases where: a) evidentiary witnesses and cross-examination were utilized, b) defense witnesses were cross-examined; c) evidentiary witnesses were utilized and defense witnesses were cross examined. Finally, a value of 4 was assigned to those cases where evidentiary witnesses were utilized and both defendant and defense witnesses were cross-examined. This was the fullest utilization of the "adversary process" by the prosecution. A similar rate of values was constructed for vigor of defense according to the criteria set forth below:

Defendant speaks for self

Defendant speaks + character witness

Only character witness

Defendant speaks, character witness + evidentiary witness

Defendant silent, character witness 
The Legal Complexity Index (LCI) is the additive resultant of these variables, and is presented in Figure 11. The figure also relates shifts in legal complexity (the LCI) with and the proportion of cases going to trial over time. ${ }^{26}$ It shows that as complexity increases the proportion of cases going to trial decreases. That is, as legal complexity increased, trials decreased. This suggests support for my central thesis, that as trials became more vigorous and complex, lawyers came to rely on an alternative, the guilty plea.

\author{
Cross-examination \\ Cross-examination + defendant speaks \\ Cross-examination + character witnesses \\ Cross-examination + defendant speaks + character witness \\ Cross-examination + evidentiary witnesses \\ + defendant speaks + evidentiary witnesses \\ Full defense (defense speaks, cross-examination, \\ character + evidentiary witnesses) \\ "Unknown/unclear/NA" \\ "no defense indicated" \\ "Defense. admits guilt" + evidentiary witness
}

Admittedly the breakdown of these categories for both vigor of prosecution and defense is somewhat arbitrary. However the categories do capture general trends and reveal cumulative increases in at least these selected aspects of trial complexity and vigor. Obviously a host of highly subtle factors shaped the development of more vigorous adversarial proceedings and more complex trials. The indicators we have used no doubt only scratch the surface as it were. Nevertheless a systematic presentation of even this surface over time can reveal some basic contours. That is despite their limitations, we do feel that this index does capture certain basic and systematic aspects of vigor and complexity, and hence can be useful in revealing broad patterns. At a minimum it can be viewed as a supplement to anecdotal evidence. Anecdotal evidence can reveal certain significant factors in especially noteworthy cases, for instance when a new procedure was first introduced and the like. But it cannot not so easily be used to show broad patterns in ordinary cases across long periods of time, which is the object of the enterprise here.

Finally we created three other variables, "expert witnesses", "matters of law", and "questions of evidence or procedure". They are all binary; thus a value of "1" was assigned to the index for each one present and a " 0 " if not.

26 One difficulty with the index is that once all controls are utilized (removing cases where the nature of defense, prosecution, etc. is "unknown"), the number of cases drops substantially in the first year (1687) to four. Further it appears that these four cases were more complex than average. (Among other things, they were described in much greater length in the OBSP than were the vast majority of other cases in that year.) Generally, however, the other sample years contained enough cases to warrant faith in the trend the index reveals. 


\section{Conclusion: The Impact of Lawyers on the Criminal Process - The Rise and Decline of the Adversarial Trial}

This article has outlined the transformation of the criminal process over a two hundred year period. It has not presented a comprehensive description of developments, nor developed a definitive explanation for the observed changes. Nevertheless by focusing on basic structures, it has described a major transformation in the nature of the criminal process, and related these changes to a handful of structural factors. The evidence supporting my thesis is overwhelming. Certainly, as indicated by the indicators examined in this article, a profound change in practices occurred in the nineteenth century. ${ }^{27}$ The key to these changes, explored in the last section of this article, appears to be increased participation by lawyers. Once they began to appear in increasing numbers, they worked a profound and far-reaching change on the criminal process. As the role of lawyers increased, the role of the jury shrank - as indicated by the variable "jury independence" and still other factors. Similarly, as lawyers appeared more frequently, evidentiary witnesses came to be used more frequently and character witnesses less frequently. More generally, lawyerization led to insistance on the formalities of evidence and procedure. All this complicated the criminal trial as was seen in the trend towards increasingly longer and more complicated trials. And with these developments came the rise of the guilty plea process and eventually plea bargaining. The key to all these changes was the lawyerization of the process. Although the modern rules of procedure and evidence were introduced in the eighteenth century and occasionally immediately thereafter, it was not until lawyerization took hold, that lawyers began to appear at trial in large numbers, that ordinary trials became more complicated and adversarial. But when this occurred, the lawyers immediately developed a new alternative, the guilty plea process and plea bargaining.

Historians of the English criminal process locate the development and introduction of modern rules of evidence and procedure in the

27 I emphasize the term practice, because I am interested in exploring and explaining changes in practices. In particular, I want to emphasize that while I agree with the leading historians who have located the formative period for formal changes in procedure and evidence in the eighteenth century, as they affected practice, my data suggest that in ordinary criminal cases these changes did not have much impact until the nineteenth century, when lawyers came to be routinely used. 
eighteenth century. ${ }^{28}$ Yet we found little impact of these innovations throughout the eighteenth century and well into the nineteenth. At least for the ordinary criminal trial, the traditional trial remained more or less unchanged until well into the nineteenth century. A trial for an ordinary offense in $\mathbf{1 8 3 5}$ was not much different in terms of the nature of the proceedings than a trial one hundred years earlier. At the turn of the nineteenth century there were occasional trials in which the judge invoked the rule against hearsay evidence, often because a lawyer objected to it, but most cases did not involve lawyers who could bring up such matters and only a few cases involved witnesses who were examined extensively. It was not until the third quarter of the nineteenth century that the modern form of the adversary trial appeared with any frequency in the bulk of ordinary criminal cases.

Whatever the reasons for the pace of these developments, it is clear that the contested adversary trial for ordinary criminal cases is relatively new. Although Anglo-American lawyers celebrate the ancient and venerable history of the jury trial, the vigorous adversarial trial in ordinary criminal cases is only little more than one hundred years old. Furthermore, as soon it emerged, an alternative process sprung up to replace it in the vast majority of all criminal cases. In short, a bifurcated process arose: increasingly complex trials for a handful of cases, and guilty pleas - and plea bargaining - for the vast majority. This pattern, which the data considered in this article found to be firmly established by end of the nineteenth century, has expanded still further in the twentieth century. Now at the end of the twentieth century in both England and the United States, and elsewhere in common law countries - vigorously contested jury trials constitute a very small portion of all criminal adjudications. Plea bargaining has become the norm. The once important judge and jury of the eighteenth century who reviewed evidence, assessed moral character, granted mercy and imposed exemplary justice in a brief but vigorous public hearing called a trial have been replaced by a prosecutor and defense attorney who negotiate the same factors privately or at least in locations other than the courtroom before a jury. Now they, and not a judge and jury, for all practical purposes secure a conviction and settle on a sentence leaving it to the judge to ratify their decisions. 
On the surface this shift in mode of decisionmaking - from jury trial to plea bargaining - appears to be a major transformation in the criminal process. And in an important sense, it is. Certainly different officials now make crucial decisions. And certainly it represents the decline of importance of a venerable institution. But despite this transformation, there are significant continuities in the process. Like the jury trial of old, the new process of negotiated pleas is also brief. Like the jury trial of old, the guilty plea mixes and merges considerations of guilt with assessments of character and concerns of mercy that blur both sets of issues. Like the jury trial of old, there remains flexibility and vast discretion in the process. And like the jury trial of old, there are ample opportunities to mitigate or circumvent harshness. In light of these factors, there may less change than at first there appears to be. Discretionary decisionmaking may have shifted from the jury and the judge to lawyers. This of course is not insignificant. But fundamental differences in the nature and quality of justice administered in ordinary cases are not readily apparent. Certainly the vast array of protections that were created in the eighteenth century but which were largely honored in the breach in ordinary cases and which began to be routinely available only in the mid-nineteenth century, have never been employed vigorously and routinely in ordinary criminal cases. On the other hand, new options have been created. The criminally accused did and do have access to the new vigorous and complex jury trial. And they have access to lawyers to advice them and negotiate in their behalf.

Still, what we have found here is that just as the adversarial criminal trial emerged in full bloom, the professionals took charge and created an alternative. To return to the issue raised at the outset of this study. There is a tendency to decry plea bargaining, to claim that it represents the "twilight of the adversary process", that it has replaced the vigorous jury trial. But as we have seen, such beliefs rest more on myth than fact. This study has found that the contentious, adversarial jury trial in ordinary cases is of relatively recent origin, and that almost as soon as it developed, it was replaced by another institution which could rapidly handle criminal cases. To be sure there are important differences, but on balance and when viewed from an historical perspective, plea bargaining may very well represent an increase and not a decrease of adversariness in ordinary criminal cases, and one that has expanded and not contracted the powers of the accused. 
A Note on the Sample

The discussion in this paper is based on an examination of over 3500 coded cases from The Old Bailey, London's Central Criminal Court, drawn from a $25 \%$ sample for roughly every twenty years from 1687, the first year for which records were available to use, to $1912 .{ }^{29}$

29 For a more detailed discussion of this sample, see Malcolm M. Feeley and Deborah Little, "The Vanishing Female: The Decline of Women in the Criminal Process, 16871912", (1991) 25 Law and Soc. R. 719. 